\title{
The historical context of the Accra Confession
}

Author:

Averell Rust ${ }^{1}$

\section{Affiliation:}

${ }^{1}$ Faculty of Theology,

University of Stellenbosch,

South Africa

\section{Correspondence to:}

Allan A. Boesak

e-mail:

boesak@mweb.co.za

\section{Postal address:}

Postnet Suite 285, Private

Bag X15, Somerset West

7130, South Africa

\section{Keywords:}

Accra confession;

globalisation; reformed church; World Alliance of Reformed Churches; economic justice

\section{Dates:}

Received: 21 Aug. 2008

Accepted: 10 June 2009

Published: 06 Nov. 2009

How to cite this article: Rust, A., 2009, 'The historical context of the Accra Confession', HTS Teologiese Studies/ Theological Studies 65(1), Art. \#280, 6 pages. DOI: 10.4102/hts.v65i1.280

\section{This article is available} at:

http://www.hts.org.za

\section{Note:}

This article was originally presented as a paper at a meeting of the Joint Globalization Task Team of the Reformed Churches of Germany and South Africa, held at Arnoldsheim, Frankfurt, Germany, 26-30 May 2008.

(c) 2009. The Authors. Licensee: OpenJournals Publishing. This work is licensed under the Creative Commons Attribution License.

\section{ABSTRACT}

This article places the Accra Confession, accepted at the 24th General Assembly of the World Alliance of Reformed Churches (WARC) (2004), within the historical context of the WARC's struggle for economic justice in the face of globalisation. It moves beyond addressing such issues merely as ethical issues to rather viewing them as confessional issues of faith. It highlights the difficulties of the WARC to reach consensus on issues concerning economic justice. It also shows how the WARC has taken the lead in the ecumenical movement by engaging a broad spectrum of people - professionals and non-professionals, from the North and the South, rich and poor - to ensure that such a confession is a true reflection of the experiences of people at grass-roots level and that it speaks from the heart. The Accra Confession challenges Christians to take a faith stance on economic injustice.

\section{INTRODUCTION}

The Accra Confession was adopted at the 24th General Assembly of the World Alliance of Reformed Churches (WARC) in 2004 to address issues of economic justice and the destruction of the earth (ecology) (WARC 2004). This confession is the culmination of a long journey of the WARC and other ecumenical movements to address these issues locally and globally from the perspective of Christian faith. The aim of this article is to place the Accra Confession in its historical context, especially regarding the WARC's search and struggle for economic justice in the face of economic globalisation.

The WARC has a long history of involvement in issues concerning economic justice. Especially since the late 1970s the WARC has focused strongly on the concept of covenant. It is from the perspective of covenant that the issue of justice in the broader sense and economic justice in particular, as dealt with by the WARC, should be understood.

The World Council of Churches (WCC) at its assembly meeting in Nairobi in 1977 launched a programme known as the Just, Participatory and Sustainability Society (JPSS). The JPSS dialogues led to a renewed ecumenical interest in God's presence in creation, in the role of humanity within creation, and in the intrinsic conflict between the competing needs of humanity and creation. Throughout the JPSS dialogues, covenant emerged as a biblical metaphor through which cohesion could be found for these concerns. As part of the ongoing WARC study on the biblical concept of berit (covenant), the concepts of peace (shalom), justice (sedaka) and right (mispat) were dominant (Kraus 1979:258). Kraus (1979:267) puts it as follows: 'If God's covenant means that man is claimed and sanctified for God, this has far-reaching implications of an ecclesiological and social ethical kind.'

According to Gollwitzer (in Kraus 1979:268), 'the community living in the covenant of God is a group which lives a transformed life and radiates change'. From this follows certain social and ethical principles which are derived from the covenant order of communion. Ellul (in Kraus 1979:268) describes the covenant as a 'treaty of allegiance' and argues that these social and ethical principles are to be sought and found afresh again and again 'on the way', in history, in 'creative discipleship'. Walter Brueggemann points out that in Jeremiah 34 and Nehemiah 5, 'covenant' has direct and inescapable implications for economic relationships. According to him, these texts suggest that matters of economic justice take priority over matters of political peace. Economic justice is perceived as a precondition to a secure, viable, humane order in society (cf. Brueggemann 1998:109-112; 2008:99-109).

In the first half of 1983, the WARC issued a statement to its member churches to form a 'covenant for peace and justice' and, a few months later, the World Council of Churches urged the churches to engage 'in a conciliatory process of mutual commitment (covenant) to justice, peace and the integrity of creation' (Vischer 1989:15).

Although the church has a long history, spanning centuries, of dealing with economic issues, it was particularly during the 1980s that churches and ecumenical bodies began expressing a deep concern about the challenges of prevailing economic trends to the Christian faith and to the ethical convictions of Christians who are involved in public matters and economic processes.

The executive of the WARC met in Geneva in August 1981 to work on a draft study on issues such as the catholicity of the church, confession and the act of confessing, worship, power and wealth, racism, and the theological basis of human rights. These papers were published in the Study guide for delegates in preparation for the Ottawa General Council in 1982 (WARC 1982a). In the paper by Charles C. West, 'Human wealth and power', the challenge was put to the WARC member churches ${ }^{1}$ to bear witness in a world where powers and principalities are constantly defying the purpose of God and the lordship of Christ. The following ways in which churches could do so were suggested:

\footnotetext{
1. See West, C.C., 1982. 'Human wealth and power', World Alliance of Reformed Churches, Ottawa 1982, viewed 17 September 2009,
} from http://warc.ch/where/21gc/study/07.html 
- responsible participation in the power structures of the world with the aim of making them more human and more just;

- an alternative witness in the life of the church but on behalf of society as a whole, which refers to a simpler Christian lifestyle that goes against consumerism and greed;

- expressing obedience to God by taking political responsibility through active resistance to unjust power structures.

In August 1982, the assembly of the WARC issued statements on peace and justice, and requested the urgent attention of churches to several global problems. Soon after the 22nd General Council in Seoul, the WARC turned to global economic injustice in the context of Christian faith (WARC 1982b). This was part of the WARC project 'Reformed Faith and Economic Justice'. Many study documents, declarations, Bible studies and so forth were subsequently devoted to economic injustice as an issue of faith.

The report of The Justice, Peace and the Integrity of Creation Committee submitted to the General Council (in Seoul) was presented as an open letter to the children and young people of the planet. On the issue of justice, the report makes mention of some countries that invest large amounts of money in buying arms while millions of people live in poverty. Its vision of the future is articulated as follows: 'But if the world is to be changed, if the "differences" that "could be" are to be realised, then the present global economic order will have to be altered drastically' (WARC 1989:135). The document emphasises that the present world economic order and structures are unjust at their very core. As long as they are maintained, the enormous gap between rich and poor will continue to grow.

In 1992, a small consultation was convened in Geneva in order to design a project. In August 1992, in Wellington, New Zealand, the executive drafted a letter to WARC member churches, which read as follows: ${ }^{2}$

We want to listen to the laments, the prophetic critique, the commandments and the visionary expressions of hope for the hopeless in the Bible. We want to turn to the sources of our faith in order to resist the temptation to accept a status quo which is unbearable for many and unsustainable for all in the long run ..

(WARC 1992:n.p.)

In order to deal with economic injustice as a faith issue, it was important that Christians gained an understanding of economic realities, trends and practices. Because Christians from all over the world had a different understanding of economic justice, it was important to find a way to work towards a common understanding, a consensus on how to act within the realm of economics. With this goal in mind, the Executive Committee of the WARC, at its meeting in Pittsburgh in 1994, adopted a programme of regional conferences. These conferences subsequently took place in Manila in the Philippines (March 1995), Kitwe in Zambia (October 1995) and San Jose in Costa Rica (May 1996).

\section{MANILA, PHILIPPINES (MARCH 1995)}

The meeting in Manila in 1995 (WARC 1995a) was the first in preparation of the 23rd General Council of the WARC which was to take place in Debrecen, Hungary, in August 1997 (see WARC 1997). The theme was 'Reformed Faith and Economic Justice', with 31 participants, primarily from Asian member churches. Besides church representatives, there were environmentalists, economists and a businessman, all of whom studied and discussed the economic, socio-political and theological aspects of the theme. A 12-page document summarising the Bible studies, panel discussions and results of the working groups was prepared. The focal point of this meeting was 'The Cry of the People' - a phrase which is reflected in the processus confessionis as

2.WARC 1992, 'Faith and economic life', Wellington, New Zealand, August 1992. Letter to member churches from the executive committee laid the foundation for the Alliance study on Reformed faith and economic justice (1992-1997), viewed 18 September 2009, from warc.ch/pc/rfej/index.html. accepted in Debrecen. Three characteristics of the new economic situation in Asian countries were identified as follows:

\section{- Process of economic growth}

Through the process of economic growth big transnational corporations (from Japan and Western nations) dominate the 'new industrialised countries', namely South Korea, Taiwan and Singapore. Migrant workers are 'trapped between exclusion and exploitation' (WARC 1995a).

\section{- Increasing power of financial capital}

Financial capital is gaining control of and determining the economic life and destiny of Asian people. This increasing power of financial capital has the implicit support of the International Monetary Fund (IMF) and other financial institutions.

\section{- Media}

The media is an important instrument of the market. Commercial advertising is creating a situation where people focus on greed rather than on need. The growth of consumerism is having a negative effect on values and attitudes. The values of the market are impacting on cultural values.

The many paradoxes in the ongoing economic process experienced by Asian nations were pointed out. This economic situation and these trends are contradictory to the basic tenets of the Reformed faith. The consultation concluded with, among others, the following challenge:

That in the worldwide fellowship of the WARC we appeal to Reformed Christians in the overdeveloped countries to acknowledge that their profit-centred economies place an unbearable burden on the global economy and on poor people all around the world, in violation of God's covenant with the earth and with people, and to join the struggle for an alternative society by opposing the concentration of economic power in their lands, the re-colonization of other parts of the world, and the pursuit of a life style which is based on the exploitation of the resources and labour of other peoples.

(WARC 1995b:n.p.)

\section{KITWE, ZAMBIA (OCTOBER 1995)}

In his keynote speech to the WARC European Area Council in Edinburgh, Scotland, in September 1995, the general secretary, Milan Opočenský, suggested that the problems concerning the confessional issue should be addressed in the context of the status confessionis. This would be done during this second regional consultation in Kitwe. The consultation examined the working hypothesis that 'injustice today means exclusion from the contemporary economic mechanism'. The working document consisted of three parts, namely 'seeing, judging and acting' (see Russel Botman's [1997] reference to Opočenský, and the discussion of the concept 'processus confessionis', used in 1995) $)^{4}$.

It was found that large parts of Africa have already been declared dead as far as the global economic map and the global economic plans of G-7 countries are concerned. The systemic impoverishment of Africa has led to many people losing their capacity for self-help and self-employment. The global-market economy claims a freedom that belongs only to God and thereby usurps the sovereignty of God, raising the question of idolatry and human loyalty to Mammon rather than to God. The idolatrous and dehumanising nature of the contemporary global

3.WARC 1995b, 'Reformed faith and economic justice', WARC-SAARC Consultation, 12-17 October, Mindolo Ecumenical Foundation, Kitwe Zambia, viewed 18 September 2009, from www.stichtingoikos.nl/dialogs/download. aspx?oid=f4db8a0.1

4.See Botman, R., 1997, 'A Warc-south initiative', first appeared in Update 7(1), March 1997, viewed 18 September 2009, from warc.ch/pc/ffej/07.html. 
economy can be seen in the exclusion of Africa and Africans from the human family.

The consultation concluded that the African reality of poverty caused by the unjust economic system has gone beyond an ethical problem to a theological one. It was the conviction that the gospel to the poor is at stake, with reference to the Confession of Belhar, ${ }^{5}$ and a status confessionis was called for. ${ }^{6}$ Milan Opočenský remarked about the Confession of Belhar that ' $[\mathrm{i}] \mathrm{t}$ was perhaps the first time that a Reformed confessional statement spoke so explicitly about social injustice, peace, suffering and need, or about the powerful and privileged who selfishly seek their own interests' (Duchrow 2002:16).

With reference to the status confessionis, the WARC 22nd General Council, Seoul, 1989, stated the following:

Any declaration of a status confessionis stems from the conviction that the integrity of the gospel is in danger. It is a call from error into truth. It demands of the church a clear and unequivocal decision for the truth of the gospel, and identifies the opposed opinion, teaching or practice as heretical. The declaration of a status confessionis refers to the practice of the church as well as to its teaching. The church's practice in the relevant case must conform to the confession of the gospel demanded by the declaration of status confessionis. The declaration of a status confessionis addresses a particular situation. It brings to light an error which threatens a specific church. Nevertheless the danger inherent in that error also calls in question the integrity of proclamation of all churches. The declaration of a status confessionis within one particular situation is, at the same time, addressed to all churches, calling them to concur in the act of confessing.

(Perret 1990:173-175)

Several concrete proposals were made and member churches were called to bring good news to the impoverished masses of Africa and to promote alternative economic practices, guided by the needs of human beings and respect for nature. The WARC was furthermore urged to have a pre-conference of member churches from the southern hemisphere to advise the General Council on the calling of a confessional movement of the churches of the South and others who are in solidarity.

\section{SAN JOSE, COSTA RICA (MAY 1996)}

At this conference, globalisation as an obstacle to the development of relationships among people was discussed from a Latin American perspective. It was found that there is asymmetric growth and a lack of access to the capital and technology needed for integral development. The problems that concern the whole of Latin America were described as a 'culture of corruption; monopolization by minorities which do not use land in a productive way; militarism; rapid change of technologies; external debt which becomes an "endless debt" ('Processus confessionis', Proceedings of the 23rd General Council of WARC, held in Debrecen, Hungary, August 8-20, 1997, p. 198, quoted by Brueggemann 2001:33).This results in hopelessness and individualism. Attention was also drawn to the fact that the gospel is often misused by great powers as a means of conquest and for political and economic domination. The relationships between first-world and Latin American churches were furthermore bemoaned as paternalistic instead of partnershiplike.

\section{GENEVA, SWITZERLAND (MAY 1996)}

At the international consultation in Geneva in 1996, the process of the regional meetings was evaluated. A study text for the delegates of the 23rd General Council at Debrecen, Hungary was also prepared. The consultation declared that the affirmation of life, commitment to resistance against injustice and the struggle

5. The Confession of Belhar was adopted by the DRMC (now the URCSA) in 1986 as a fourth confession.

6.A status confessionis is the Latin term meaning that the truth of the gospel is at stake. for transformation are an inseparable part of Reformed faith and confession today. An act of repentance, as a new beginning, is therefore necessary; Christians from the Reformed tradition have to confess their complicity in the global system and their insensibility to the victimisation of people (see 'Processus confessionis', in Brueggemann 2001:33). WARC member churches must continue to discern the suffering of the household of the poor and the weak due to globalisation. They should enter into consultation with the key actors of the global economic system. They should also enter into the liturgical movements of tithing, of celebrating the Sabbath and Jubilee and of confessing guilt of involvement in globalisation.

\section{DEBRECEN, HUNGARY (AUGUST 1997)}

At the 23rd General Council in Debrecen, Hungary in 1997, the theme was taken from Isaiah 58:1-12, 'Break the chains of injustice'. Drawing on the earlier consultations and other study documents presented at the meeting, key characteristics of globalisation were described and some results of its impact were reiterated. In light of the Kitwe consultation the question was raised whether or not it was possible to declare a status confessionis regarding economic injustice, especially with regard to the exclusion of Africa from the market mechanism. Instead, however, the Council adopted a call for a committed process of recognition, education, confession and action regarding economic injustice and the destruction of the earth (Processus Confessionis). This Processus Confessionis was also referred to as 'Covenanting for justice in the economy and the earth'.

The Council also adopted 'The Declaration of Debrecen', which was based on the popular notion of Calvin that 'we are not our own'. In respect of the answer to the first question of the Heidelberg Cathechism, the following was asserted:?

In many parts of the world, Reformed churches and communities are challenged by the appalling circumstances in which many people live and by the threat of the ongoing destruction of the environment. Many believe that the time has come to make a confession of faith which rejects and struggles against these injustices, while affirming our faith in the triune God who in Christ offers a new creation. We are challenged by the cry of the people who suffer and by the groaning of creation. We Christians of Reformed churches are aware of our complicity in an economic order that is unfair and oppressive, leading to the misery and death of many people. We participate in attitudes and practices which erode the foundations of the earth's livelihood. We want to affirm the gift of life. We consider this affirmation of life, commitment to resistance, and struggle for transformation to be an integral part of Reformed faith and confession today. In the past we have called for status confessionis in cases of blatant racial and cultural discrimination and genocide. We now call for a committed process of progressive recognition, education and confession (processus confessionis) within all WARC member churches at all levels regarding economic injustice and ecological destruction.

(WARC 1997:n.p.)

According to Opočenský (1997:197-199) this in effect means that:

- the church should pay special attention to the analysis and understanding of economic processes

- churches should educate their members at all levels on economic life and how to develop a lifestyle which counteracts the materialism and consumerism of our day

- churches should work towards the formulation of a confession of their beliefs about economic life which would express justice in the whole household of God

- churches should act in favour of the victims of injustice.

After the General Assembly meeting in Debrecen, the WARC prepared for the 24th General Assembly meeting to be held in Accra, Ghana, in 2004. Further discussions on the processus confessionis followed.

7.WARC 1997, 'The declaration of Debrecen', viewed 18 September 2009, from warc. $\mathrm{ch} /$ where/23gc/declar.html. 


\section{BANGKOK, THAILAND (NOVEMBER 1999)}

At the 8th General Assembly of the World Council of Churches (in Harare in 1999), the meeting decided to join the WARC with the initiative of the processus confessionis. The symposium in Bangkok can be seen as the first step in this cooperation, with the theme 'Consequences of Economic Globalisation'. The main focus was to hear the stories and experiences of people at grassroots level in the light of the Asian crisis. They showed clearly how one of the costs of the crisis was an escalating movement toward the informal sector, which resulted in an exposure of the urban and rural poor and the marginalised to further deteriorating life conditions.

A distinction is made between the 'first-order' consequences of an economic crisis, which can clearly be seen in statistics, 'second-order' economic and social consequences, which appear only partially in statistics, and 'third-order' consequences, which only become visible over time.

The term 'first-order consequences' refers to the flood of bankruptcies and lay-offs that occurred because loans could no longer be repaid and because of a general rise in prices due to the strong depreciation of the local currency (the baht). Fifty-six financial companies had to close down and, in the construction sector, about one million workers lost their jobs within two years.

'Second-order consequences' occurred when policy makers began to react to this new situation and programmes were developed for 'rapid economic recovery'. In most of the southeast Asian countries (except Malaysia), the International Monetary Fund imposed certain programmes as a condition for financial aid. For Thailand, for example, this meant severe restrictions on government expenditure, high interest rates and a significant rise in taxes on consumption (VAT). As a result spending on social services fell by almost $10 \%$ and spending on public health fell by $6 \%$ in one year.

'Third-order consequences' are the most severe. They relate to what happens to people and their environment in the medium and long terms when social and cultural consequences become clear. It can be described as follows:

The inevitable conclusion is that the Asian crisis cannot be seen as an isolated financial crisis. It has spread like a cancer throughout the whole society, causing continuing damage at the level not only of "human capital" (deterioration in health, school dropouts), but also of social capital (loss of sense of trust, community, social peace) and natural capital (loss of care for the land, use of more aggressive fertilizers, sale of forests in Indonesia to international investors).

(WARC 1999:n.p.)

\section{CAPE TOWN, SOUTH AFRICA (MARCH 2001)}

This consultation was organised with the purpose of helping member churches and the wider ecumenical family to understand the theological basis of the process. The consultation came to the following conclusions:

- It was recognised that the global economic system justifies itself and seeks to replace God's sovereignty over life. It does this through six separate but integrated actions: economic exclusion, economic speculation, political erosion, military protectionism, cultural control and domination for profit.

- Listening to excluded people, 'we hear that the current global economic power does not aim at the preservation of life, the

8.WARC 1999, 'Bangkok 1999: Globalization and its consequences', viewed 18 September 2009, from warc.ch/pc/bangkok/07.html. A report on the symposium on the consequences of economic globalisation in Bangkok, Thailand (November 12 to 15 1999), organised by the World Alliance of Reformed Churches, the World Council of Churches, the Christian Conference of Asia, the Asian Cultural Forum Covi of Chur the Chy by WARC, the WCC, and the Korean Council of Churches. restoration of human dignity, the building of the common good or stewardship of creation' (Cape Town 2001).

- The importance of the life-centeredness of the economy, its biblical mandate and the security of people was emphasised.

- Mention was made of what we can learn from the Reformed tradition, in particular from John Calvin, the Barmen Declaration (Germany) and the Confession of Belhar (South Africa) regarding economic injustice.

- John Calvin: It was observed that Calvin had no time for the idea of a value-free economy, for God will do justice and liberate the exploited.

- The Barmen Declaration: 'We reject the false doctrine, as though there were areas of our life in which we would not belong to Jesus Christ, but to other lords - areas in which we would not need justification and sanctification through him.'

- Confession of Belhar: 'We believe that God has revealed Godself as the one who wishes to bring about justice and true peace among men; that in a world full of injustice and enmity God is in a special way the God of the destitute, the poor and the wronged and calls God's church to follow in this way; that God brings justice to the oppressed and gives bread to the hungry ...

\section{BUDAPEST, HUNGARY (JUNE 2001)}

At this consultation, the emphasis was on the ecological, economic and social consequences of globalisation in Central and Eastern Europe. It was about a decade ago that communism collapsed and that people rejoiced in their new freedom. However, in 1989, about 14 million people in the former communist block lived on less than $\$ 4$ a day. By the mid-1990s, that number had risen to 147 million people. A decline in health care, schooling and education standards was visible

The role of the state was minimised and the poor were left without protection and support. The consultation came to the conclusion that no authority either inside or outside the region should escape its responsibility to do justice to the poor and the needy by claiming that globalisation and its consequences were unavoidable. There was a call to governments and the wider public in the region to serve people, not power, and a call to churches to choose life, not death.

\section{SOESTERBERG, NETHERLANDS (JUNE 2002)}

The theme of the Soesterberg consultation was 'Economy in the Service of Life'. The two major objectives of the Western European consultation were:

- to analyse how economic globalisation and the role of money affect societies in Western Europe;

- to develop a response by Western European churches to questions raised by churches in Central and Eastern Europe and in the South.

The importance in engaging in encounters with key institutions in the process of economic globalisation was emphasised. The assumption that 'there is no alternative' to economic globalisation guided by the neo-liberal economic doctrine and that economic globalisation is a leaderless process was strongly rejected. The impact of European integration was also mentioned.

\section{BUENOS AIRES, ARGENTINA (APRIL 2003)}

This consultation was attended by members of the South-South Churches' Forum of the WARC; the theme of the consultation was 'Faith stance on the global crisis of life'. These member churches included churches from Asia, Africa, the Pacific, the Caribbean and Latin America. The significance of this meeting was that it was the first collective response of the southern member churches to the Debrecen call (processus confessionis). Mention was made that this period in the world's history was acknowledged as a kairos, challenging us to decisive action. It 
was said that the neo-liberal model cannot be transformed or adjusted: it has inherent contradictions and has failed again and again to lift the countries, peoples and natural environment of the South out of their misery and towards life. It was argued that, through neo-liberal globalisation, the economy, designed to sustain life and the well-being of all, has become a totalitarian faith system of wealth accumulation for the few, endangering life as a whole on the planet. This system is structural sin; globalised neo-liberalism is in complete contradiction to the central tenets of the Christian faith. The consultation came to the conclusion that neo-liberal ideology claims absolute power over and against the sovereignty of God and gospel claims and that it is therefore critical for 'the integrity of our faith, that we take a faith stance'. God's economy was furthermore contrasted with neo-liberal globalisation (economy) (see Table 1). ${ }^{9}$

The following practical guidelines for resistance to the economy were given:

- Church members should participate in people's movements in civil disobedience against increasing consumption levels. The richness of sufficiency needs to be learned again, especially by the rich.

- Church members should resist if their own churches want to invest church money in the most profitable way that bypasses the basic needs of the poor, who need access to capital to build up their livelihood.

- Churches should press for the democratic redesign of the international financial and economic system, replacing present institutions (the International Monetary Fund, the World Bank, the World Trade Organisation), which are owned mainly by rich countries and therefore serve their own economic and financial interests.

- Churches should not stand on the side of big land owners but on the side of small owners and the landless people.

\section{ACCRA, GHANA (2004)}

Debrecen called on the WARC member churches

to work towards the formulation of a confession of their beliefs about economic life which would express justice in the whole household of God and reflect priority for the poor and support an ecologically sustainable future.

(Opočenský 1997:199)

Through the consultations mentioned above, the Executive Committee worked towards a draft confession, which resulted in the Accra Confession adopted at the 24th General Council meeting held in Accra, Ghana, in 2004.

\section{CONCLUSION}

This long journey undertaken by the WARC, especially concerning the issue of economic justice, indicates the seriousness with which the WARC has grappled with the issue. Through this journey WARC has also played a major role in influencing other ecumenical bodies.

The consultations, working groups and discussions received inputs from a very broad base of people, namely professionals, labourers, the illiterate, theologians and economists. The process was based on that of the Kitwe Consultation, namely seeing, judging and acting, as well as on the process accepted at Debrecen, namely a committed process of recognition, education and confession. The importance of the input of churches from both the North and the South, separately and together, cannot be underestimated.

Given the history and identity of the organisation, it could not have been an easy decision for the WARC to continue on this journey. A critical question for the WARC was how to

9.See Seon-Won Park, 2005, 'What really happened at Accra on the issue of neoliberal economic globalization?', viewed 18 September 2009, from warc.jalb.de/ warcajsp/side.jsp?news_id=348\&part_id. secure consensus from member churches. In what way has such consensus been reached? De Santa Anna has remarked as follows:

[T] his wide awareness of Christian churches about the relevance of the challenges of economic realities to Christian faith in its aim to witness for justice is far from being accompanied by a consensus about how Christians are called to act in the realm of the economics.

The debate on whether the 'integrity of our faith is at stake' has moved beyond an ethical discussion to a theological one. It proceeded to the call for a status confessionis/processus confessionis. These discussions and decisions were greatly influenced by, among others, the Barmen Declaration, the Confession of Belhar and the peace ethics debate concerning nuclear weapons (from the 1950 s to the early 1960s).

Vischer has commented on the position of the WARC concerning confessions and by pointing out that the Reformed churches have never united around a single, common confession of faith. The Reformed confessions were formulated by individual churches in their different situations and none of these confessions has been recognised by the Reformed churches as the Reformed confession. Vischer puts it as follows:

Even though the Reformed churches are not united by a common confession of faith, there are fundamental doctrinal statements on which they are de facto agreed. Almost all of them assign a central place, for example to the "covenant" concept in the presentation of Christian doctrine. They are united by the emphasis they place on the Word of God. They are distinguished by a definite spirituality; as a rule they consider it their task to make the claims of the Gospel operative in the common life of society. But can the common basis uniting the Reformed churches be defined at all in terms of certain common features and characteristics? The constitution of the Reformed Churches is right perhaps to define the Reformed tradition as a biblical, evangelical and doctrinal ethos.

(Vischer 1985:264)

Reformed churches are therefore united not by a particular confession, not by a particular liturgy, not by a particular order, not by a particular spirituality, but by a common ethos (Reformed World 1985:264). Given this identity of the WARC, it was a great challenge to journey with member churches towards consensus, a common understanding and a confession.

This covenanting for justice in the economy and the earth process has indeed contributed to challenging WARC member churches and others to give an account of their Christian conviction and Reformed faith in the light of economic injustice and ecological destruction.

On this continuing journey, because of the complexity of related issues concerning economic injustice, members disagree on, for instance, various approaches, interpretations and actions influenced by their various contexts. However, we sincerely trust that, through the love of God, our Parent, the grace of Jesus Christ and the fellowship of the Holy Spirit, we will choose to stand where God stands alongside the destitute, the poor, the exploited, the wronged and the abused..$^{10}$

\section{REFERENCES}

Botman, R., 1997, 'A Warc-south initiative', first appeared in Update 7(1), March 1997, viewed 18 September 2009, from warc.ch/pc/rfej/07.html.

Brueggemann, W., 1998, A commentary on Jeremiah: Exile and homecoming, Eerdmans, Grand Rapids.

10.See point 4 of the Confession of Belhar, 1986 (Psalm 146:7-9). A translation of the original Afrikaans text of the confession as it was adopted by the synod of the Dutch Reformed Mission Church in South Africa in 1986. In 1994 the Dutch Reformed Mission Church and the Dutch Reformed Church in Africa united to form the Uniting Reformed Church in Southern Africa (URCSA). This inclusive language ing Re was preper by viewed 1 September 2009, from www.pcusa.org/theologyandworship/confession/
belhar.pdf. 
Brueggemann, W., 2001, Hope for the world: Mission in global context, Westminster John Knox, Philadelphia.

Bruegemann, W., 2008, Great prayers of the Old Testament, Westminster John Knox, Louisville.

Confession of Belhar, 1986, viewed 1 September 2009, from www.pcusa.org/theologyandworship/confession/belhar. pdf.

Duchrow, U. (ed.), 2002, Colloquium 2000: Faith communities and social movements facing globalization, World Alliance of Reformed Churches, Geneva.

Kraus, H.J., 1979, 'God's covenant', Reformed World 35(6), 258 268.

Opočenský, M., (ed.), 1997, Proceedings of the 23rd General Council, WARC, Debrecen.

Park, S.-W., 2005, 'What really happened at Accra on the issue of neo-liberal economic globalization?, viewed 18 September 2009, from warc.jalb.de/warcajsp/side.jsp?news_ id=348\&part id.

Perret, E., (ed.), 1989, Proceedings of the 22nd General Council, WARC, Seoul.

Vischer, L., 1985, 'Report of Methodist/Reformed Consultation', Reformed World 38(8), 444-447, 452.

Vischer, L., 1989, 'I will be your God, You shall be my people', in Ecumenical Reformed Library, viewed 18 September 2009, from warc.jalb.de/warcajsp/side.jsp?news_id=885\&part_id.

WARC, 1982a, 'Study guide for delegates Ottawa 1982', viewed 18 September 2009, from warc.jalb.de/warcajsp/news_file/ BIBECUM.pdf.
WARC, 1982b, 'Theological perspectives - Report of the Secretary of the Department of Theology: To Ottawa 1982 and onwards', Reformed World 37(1), 148-150.

WARC, 1989, 'An open letter to the children and young people of the planet', Reformed World 40(7), 132-141.

WARC, 1992, 'Faith and economic life', viewed 18 September 2009, from warc.ch/pc/rfej/index.html.

WARC, 1995a, 'Manila Consultation: Working paper', viewed 18 September 2009, from www.ccc-cce.ca/english/downloads/ mesa_cormie.pdf.

WARC, 1995b, 'Reformed faith and economic justice', WARCSAARC Consultation, viewed 18 September 2009, from www. stichtingoikos.nl/dialogs/download.aspx?oid=f4db8a0.1

WARC, 1995b, 'Manila Consultation: Working paper', viewed 18 September 2009, from www.stichtingoikos.nl/dialogs/ download.aspx?oid $=76495021$

WARC,1997, 'The declaration of Debrecen', viewed 18 September 2009, from warc.ch/where/23gc/declar.html.

WARC, 1999, 'Bangkok 1999: Globalization and its consequences', viewed 18 September 2009, from warc.ch/pc/bangkok/07. html.

WARC, 2004, 'A continuing journey towards confessing movement for economic justice and life on earth: Covenanting for justice in the economy and on the earth (processus confessionis)', viewed 18 September 2009, from http://www.kairoseuropa.de/english/continuing-journey. doc.

West, C.C., 1982, 'Human wealth and power', viewed 17 September 2009, from http://warc.ch/where/21gc/study/07. html. 